\title{
The effects of telicity, dynamicity and punctuality in L2 acquisition of Spanish Preterit and Imperfect
}

\author{
Lucía Quintana Hernández
}

Universidad de Huelva

The aim of this work is to investigate the use of Spanish Preterit and Imperfect by English speaking learners of L2 Spanish following the Lexical Aspect Hypothesis (Andersen \& Shirai, 1996; Díaz, Bel, \& Bekiou, 2008; Domínguez, Tracy-Ventura, Arche, Mitchell, \& Miles, 2013; González, 2003, 2013; Montrul \& Slabakova, 2002). The article studies how aspectual features bias Preterit and Imperfect in initial, intermediate and advanced learners. The results, based on an approximate binomial distribution analysis, confirm that Preterit is the preferred past, which supports L1 transfer (Salaberry \& Shirai, 2002). The results also verify that Preterit is biased by dynamicity and punctuality at all levels. Telicity effects come into play in intermediate levels, while punctuality effects are reinforced in advanced levels. Stativity influences the use of Imperfect in intermediate level, which reveals that there are differences in the bias effect regarding proficiency level.

Keywords: L2 acquisition, telicity, dynamicity, punctuality, aspectual features, past tenses, grammatical aspect

\section{Introduction}

Acquiring the aspectual difference between Spanish Preterit and Imperfect is a difficult process for L2 learners, also for those with L1 English. This is not surprising if we bear in mind that English does not count on this aspectual distinction. The aim of this article is to study the acquisition of aspect within the framework of the Lexical Aspect Hypothesis. Unlike previous work on LAH (Andersen, 1991; Andersen \& Shirai, 1996) and modifications of it (Comajoan, 2013; Diaubalick \& Guijarro Fuentes, 2017; Díaz, Bel, \& Bekiou, 2008; Domínguez, Tracy-Ventura, Arche, Mitchell, \& Miles, 2013; González, 2003, 2013; Montrul \& Slabakova, 2000; 
Slabakova, 2001; among others), this study does not take for granted Vendler's (1957) typology, but it tests the effects of telicity, dynamicity and punctuality in the acquisition of Spanish past verbal morphology to further understand how aspectual features affect the use of Spanish grammatical aspect.

The LAH predicts that past verbal morphology initially codes lexical aspect. Andersen (1991) found that Preterit appears first with achievements, then accomplishments, activities, and finally states, while Imperfect emerged later on first with states, then activities, accomplishments and finally with achievements. Although our work does not assume Vendler's typology, it contributes to this line of research to find out which aspectual features bias the use of the Preterit and the Imperfect in different proficiency levels $\left(\mathrm{A}_{2}, \mathrm{~B}_{1}, \mathrm{~B}_{2}\right.$ and $\left.\mathrm{C}_{1}\right)$. This reasoning is based on the idea that L2 morphological variability is the result of reassembling lexical features in the target language, as stated by the Feature Assembly Hypothesis (Lardiere, 2009), and it aims to show that the interaction of interpretable features (animacy, specificity and telicity), and uninterpretable features (accusative) in VP complicates things for L2 learners (Guijarro-Fuentes, 2012).

Previous studies proposed that telicity biases the use of past verbal morphology (Andersen, 1991; Andersen \& Shirai, 1996; Slabakova, 2001; Montrul, 2004; Díaz et al., 2008). González (2003) claimed that Dutch learners' use of Spanish verbal morphology is biased by the pair durative/terminative (Verkuyl, 1993). Domínguez et al. (2013) found out that dynamicity also biases the use of Spanish grammatical aspect. Based on Smith's (1991) aspectual features, our study focuses on three lexical aspectual distinctions (telic/atelic, dynamic/stative, punctual/durative) to find out whether there are different biases through the acquisition process. To this end, 64 English speaking learners of L2 Spanish of different proficiency levels (A2, B1, B2 and $\mathrm{C}_{1}$ ) were tested. A control group of 16 speakers of Spanish was also analysed.

The article is organized as follows. First, we briefly review the notion of Aspect. Second, the distinction between grammatical aspect in Spanish and English is presented. Third, we briefly revise empirical studies within the LAH, and introduce our proposal connected to the Feature Reassembly Hypothesis. Fourth, the study is presented. Finally the results are discussed.

\section{Aspect}

Aspect conveys the speaker's perspective on the event or state presented by a sentence. Smith (1991) proposes that aspectual meaning results from the interaction of situation aspect and viewpoint aspect. On the one hand, situation aspect refers to the inherent meaning of lexical pieces (also known as lexical 
aspect). The syntactic structure of the VP can modify the lexical aspect, thus for example, write is a dynamic, durative and atelic verb, but write two letters is a dynamic, durative and telic predicate. On the other hand, viewpoint aspect can be expressed by multiple means. In Spanish, aspect can be bounded to temporal reference in verbal morphology (grammatical aspect).

Grammatical aspect is concerned with perfective, perfect and imperfective contexts, while lexical aspect is concerned with several aspectual contrasts such as dynamic or stative situations, telic or atelic situations, and punctual or durative situations. For example, the dynamic and atelic Spanish verb escribir 'write' can appear in perfective and imperfective contexts: in Escribi tres cartas 'I wrote three letters' is uttered in a perfective context where the event of writing is completed, whereas Escribía tres cartas 'I wrote three letters' is uttered in an imperfective context where we do not know about the completion of the event.

Even though studies differ in their theoretical description of aspect, there are a few aspectual features which, in different guises, are present in most proposals: telicity, dynamicity and punctuality. For this reason, we test all aspectual features in our experiment. The aim is to clarify which aspectual features, not aspectual classes, bias grammatical aspect.

Vendler's (1957) classification is based on telicity distinctions. Achievements and accomplishments are telic whereas states and activities are atelic. Vendler's proposal cannot accommodate semelfactives, which are punctual but not telic verbs. Moens and Steedman's (1988) taxonomy (stative/eventive) is primarily based on dynamicity distinctions, but some other aspectual features are taken into account to distinguish events which have consequences (culminations and culminated processes) from those which do not (processes and points). Their proposal also distinguishes points (semelfactives) from culminations (achievements) by adding the aspectual distinction atomic/extended (punctual/durative). For Engelberg's (1999), the distinction between long and short events has a cognitive basis, and for this reason he proposes a classification into punctual and durative predicates.

Verkuyl's (1993) typology (durative and terminative) is based on the syntactic structure of the VP, and mainly on two aspectual features which are [+/-ADD $\mathrm{TO}]$ and $[+/-$ specified quantity of the argument]. Only when the two syntactic features are marked positively the predication is terminative. His contribution is very relevant for our purposes since VP is taken into account for the calculus of completion. However, since its proposal oppose durativity to terminativity, and not to punctuality, as Vendler (1957) and Smith (1991), its terminology will not be used in this paper. 


\section{Grammatical aspect in Spanish and English}

Spanish counts on three past tenses to cover perfect, perfective and imperfective contexts, i.e. Present Perfect, Preterit and Imperfect, while English has Present Perfect, Simple Past, and Past Progressive. The Preterit is used in perfective contexts in Spanish, and the Imperfect in imperfective contexts. The English Simple Past is used in perfective and imperfective contexts. The challenge for the learner is to understand that some imperfective readings (continuous and habitual) associated with the English Simple Past are expressed by the Imperfect in Spanish, and also to reject the Spanish Preterit in imperfective contexts (Domínguez, Arche, \& Myles, 2017).

\section{Aspectual features in interlanguage hypotheses}

The LAH claims that past verbal morphology is biased by telicity. However, González (2003, 2013), based on the contribution of VP to terminativity (Verkuyl, 1993), argues that Dutch learners of L2 Spanish use the perfective form with terminative predications first, and the imperfective form with durative predications later; whereas Domínguez et al. (2013) propose that learners' use of past tenses is biased by dynamicity, i. e. Preterit with events and Imperfect with states.

From a generativist perspective, Díaz et al. (2008) propose that the aspectual bias is motivated by the interaction of interpretable (telicity and specificity) and uninterpretable features (accusative) in VP. Their claim reminds us of Lardiere's (2009) proposal on feature reassembly process in L2. For her, the task of reassembling features in the target language is the source of delay in the acquisition process. Both English and Spanish grammars compute the syntactic features in VP (specificity and accusative) to calculate telicity, but only Spanish presents a differential object marker $a$ for animacy, which complicates syntactic computation (Guijarro-Fuentes, 2012). The differential object marker $a$ is not a telicity marker, but it creates an extra obstacle for English learners. The prediction is that the interaction of interpretable features (animacy, telicity and specificity), and the extra syntactic operation to value the inherent case (accusative or dative), will delay the acquisition process. That is, the Spanish L2 learner needs to be aware that the marker $a$ is not relevant for telicity but for animacy and accusative case marking, as in Juan pinto a los niños 'John painted the kids'. However, nothing is said about the other aspectual features (punctuality and dynamicity).

Considering the results of the previous studies mentioned above, we claim that the use of past verbal morphology is biased by all aspectual features at different proficiency levels. We differentiate lexical aspectual features (punctuality and 
dynamicity) from predicative aspectual features (telicity), and argue that lexical aspectual features bias grammatical aspect from early stages, while aspectual features which are related to VP structure bias grammatical aspect at a later stadium. This will be named the Refined Lexical Hypothesis.

We assume that students' initial linguistic representation is their English L1 (Slabakova, 2001; Salaberry \& Shirai, 2002); thus, in addition to dynamicity and punctuality bias, they are expected to use the Preterit in perfective and imperfective contexts at first stages, whereas telicity influences the use of past morphology at later stages.

\section{Study}

Based on English L1 transfer and the proposal that lexical aspect features bias the use of Spanish grammatical aspect at initial stages, while more syntactic aspectual features bias the use of past tenses later on (Refined Lexical Hypothesis), this study addresses these research questions:

1. Which Spanish Past tense is preferred by English learners?

2. What aspectual features bias the use of the Preterit?

3. What aspectual features bias the use of the Imperfect?

4. Is there any difference between levels $\left(\mathrm{A}_{2}, \mathrm{~B}_{1}, \mathrm{~B}_{2}, \mathrm{C}_{1}\right)$ regarding dynamicity?

5. Is there any difference between levels $\left(\mathrm{A}_{2}, \mathrm{~B}_{1}, \mathrm{~B}_{2}, \mathrm{C}_{1}\right)$ regarding telicity?

6. Is there any difference between levels $\left(\mathrm{A}_{2}, \mathrm{~B}_{1}, \mathrm{~B}_{2}, \mathrm{C}_{1}\right)$ regarding punctuality?

\subsection{Participants}

Data from 64 L1 English speaking learners from different institutions in Seville and Huelva, and a control group of 16 native speakers from the University of Huelva, were collected. We had 22 A2 L1 English learners of Spanish, 17 B1 learners, $15 \mathrm{~B}_{2}$ learners, and $10 \mathrm{C} 1$ learners. All learners had taken a leveling test before this study, and were thus placed at the CEFR appropriate level. L1 English learners of level $A_{2}, B_{1}$ and $B_{2}$ were all twenty-one years old. All of them were from the United States and have already spent three months in their second semester in a study abroad program in Seville, Spain. C1 learners were ERASMUS students in the Faculty of Humanities in the University of Huelva. 


\subsection{Methodology}

A semi-controlled written production task was designed to test the Refined Lexical Aspect Hypothesis. The task was based on a mute and short movie entitled Paroles en l' air (Vincendeau, 1995), and is appropriate for the study because the story included all sorts of situations, and therefore all sorts of predicates, in perfective and imperfective contexts. Narrative grounding was not measured in this experiment. After watching the movie, all participants had 20 minutes to write down the story. They were asked to write the story using past tenses. A previous experiment already used this task to test the effects of inherent aspect and L1 transfer (González \& Quintana Hernández, 2018). Data were coded as follows. First, all past tenses were identified and divided in two groups: Preterits and Imperfects. Second, all Preterits and Imperfects were coded taking into account the telic/atelic distinction. Third, all Preterits and Imperfects were coded according to the dynamic/stative distinction. Finally, the same was done for the punctual/durative contrast. For the aspectual distinctions, typical tests were used, such as the compatibility with en/durante 'in/for' temporal expressions, and with acabar/terminar 'finish' periphrases to distinguish telic form atelic predicates, and the compatibility with de repente 'suddenly' for the punctual/durative distinction, etc. Dynamicity was coded as involving agency, activity and change (Smith, 1991), and the compatibility with the progressive was used to test dynamicity contrasts. The researcher did the same for the four proficiency levels (A2, B1, B2, and $\mathrm{C}_{1}$ ). Afterwards, and based on an approximate binomial distribution analysis, the chisquare test was used to find significant differences among groups.

\subsection{Results}

\subsubsection{Use of past tenses}

We have analysed 1854 verbal predicates from 80 participants in the present study. Because learners did not use the Present Perfect, and progressives were just a few, only Preterit and Imperfect which were clearly identified were coded. All learners preferred the Preterit to complete this task due to storytelling structure, but also to their English L1.

Regarding our first research question, i.e. which Spanish tense was preferred, we found significant differences in the chi-square test for the total uses of past tenses among the five groups, $X^{2}(4, N=1854)=35,60, p<.001$. There are also significant differences among the four groups of learners, $X^{2}(6, N=1460)=49,28$, $p<.001$, which allows paying attention to contrast in data.

Table 1 shows the total uses and percentages of Preterits and Imperfects for the five groups of participants. Although there are significant differences among 
Table 1. Total uses of past tenses

\begin{tabular}{lcrc}
\hline & Preterit & Imperfect & Total of items \\
\hline Control group & $349(76 \%)$ & $111(24 \%)$ & 460 \\
A2 group & $286(77 \%)$ & $85(23 \%)$ & 371 \\
B1 group & $244(68 \%)$ & $102(32 \%)$ & 346 \\
B2 group & $261(61 \%)$ & $147(39 \%)$ & 408 \\
C1 group & $222(76 \%)$ & $47(24 \%)$ & 269 \\
\hline
\end{tabular}

the five groups, the Preterit is preferred by all of them, as expected due to storytelling, i.e. participants focus on narrative foregrounding. Only learners fail to use the Preterit in imperfective contexts. As pointed out in other studies (Bardovi-Harlig, 1994), the Discourse Hypothesis interacts with the LAH in constructing narrative structure, and natives' preference to focus on foreground to complete this task confirms that narrative structure should be taken into account in future research.

Regarding the contrast between the control group and learners, the chisquare test shows that there are no significant differences in the rate of use of Preterits and Imperfects between A2 learners and the control group ( $X^{2}(1$, $N=831)=0,17,0.68)$, or between the B1 group and the control group $\left(X^{2}(1\right.$, $N=806)=2,91,0.88$ ). But there are significant differences between the control group and the other groups $X^{2}(1, N=868)=14,66, p<.001$ for the contrast between the control group and $\mathrm{B}_{2}$, and $X^{2}(1, N=729)=4,43, p<.03$ for the contrast with $\mathrm{C}_{1}$. Although the chi-square test for the control group and beginners (or intermediates) does not show significant differences, descriptively speaking, only learners wrongly use the Preterit in imperfective contexts as in ${ }^{*}$ Mientras comó sacaba su cabeza por la ventana 'While he ate he looked through the window'. Native speakers use more progressives for these imperfective contexts.

Regarding the contrast among learners, the chi-square test for the total uses of past tenses for the contrast between $A_{2}$ and $B_{1}$ shows significant differences, $X^{2}(1$, $N=717)=4,01, p<.04$, which allows analysing the data. As predicted, the rate of use of the Preterit by beginners is higher than the rate of intermediate and advanced learners. Although the results of beginners are similar to the control group, we will see how aspectual features interfere in the next section. The use of Preterit decreases from $77 \%$ in $\mathrm{A}_{2}$ to $68 \%$ and $61 \%$ in $\mathrm{B}_{1}$ and $\mathrm{B}_{2}$, respectively. On the other hand, the use of Imperfect increases from $23 \%$ in $\mathrm{A}_{2}$ to $32 \%$ in $\mathrm{B} 1$, and $39 \%$ in $\mathrm{B}_{2}$. The fact that the rate of use of Imperfects increases in $\mathrm{B}_{1}$ and $\mathrm{B}_{2}$ allows us to claim that students are already aware of its use in imperfective contexts. González and Quintana Hernández (2018) show that Dutch and English learners of Spanish L2 behave differently at first stages of acquisition, which indicates L1 transfer. This 
study reinforces their claim by finding differences between beginners and intermediates.

Surprisingly, in this experiment the $\mathrm{C} 1$ group sometimes uses the Preterit in imperfective contexts, as in La película comenzó con un hombre que acabó de despertarse 'The movie began with a man who just woke up', and the use of Imperfects decreases drastically. However, the few examples show that punctuality biases the use of the Preterit, which indicates that this aspectual feature still influences the use of the Preterit in advanced learners. C1 learners keep using the Preterit in imperfective contexts when they use a prototypical combination (punctual-Preterit).

Incidentally, this association is considered a semantic universal which we find in L1 learners (Gavruseva, 2002), in creolization, and as we see in the present study, also in L2 learners. Our study, in this sense, supports Bickerton's (1981) claim about the punctual/non punctual distinction being a temporal semantic universal.

A2 learners show stronger preference for the Preterit, while B2 learners show the lowest rate of this form, which allows to confirm L1 transfer from the English Simple Past. The fact that native speakers also prefer the Preterit indicates that the type of task also biases the results. Future work will consider measuring out foreground narrating to see whether there are significant differences.

\subsubsection{Use of Preterit}

\subsubsection{Dynamicity effects with Preterit}

Our second research question was about the aspectual features that bias the use of the Preterit, and to answer it three aspectual oppositions were tested: dynamic/ stative, telic/atelic, and punctual/durative. Let's begin looking at the use of the Preterit with stative and dynamic predicates. The chi-square test for the total uses of Preterits with dynamic predicates and states for the five groups shows significant differences, $X^{2}(4, N=1362)=29,78, p<.001$, which allows paying attention to their different uses.

Table 2. Total uses of Preterit with stative and dynamic predicates

\begin{tabular}{lllc}
\hline & Stative & Dynamic & Total of items \\
\hline Control group & $85(24 \%)$ & $264(76 \%)$ & 349 \\
A2 group & $45(16 \%)$ & $241(84 \%)$ & 286 \\
B1 group & $22(9 \%)$ & $222(91 \%)$ & 244 \\
B2 group & $32(12 \%)$ & $229(88 \%)$ & 261 \\
C1 group & $34(15 \%)$ & $188(85 \%)$ & 222 \\
\hline
\end{tabular}


Table 2 shows that dynamicity has a strong effect on the use of Preterit in all levels of proficiency. That is why the chi-square test for the four groups of learners does not show significant differences. The rate of use of Preterits with dynamic predicates confirms our prediction regarding aspectual features as dynamicity, and also corroborates what other studies already found, i.e. that lexical aspect biases the use of the Preterit from beginners to advanced learners (Salaberry, 200o; Domínguez et al., 2013).

\subsubsection{Telicity effects with Preterit}

The chi-square test for the total uses of Preterits with telic and atelic predicates in Table 3 shows significant differences among the five groups, $X^{2}(4$, $N=1362)=12,30, p<.02$. Unlike the dynamicity test, the chi-square test for the groups of learners also shows significant differences, $X^{2}(3, N=1013)=11,49, p<.01$, which indicates that we must pay attention to contrasts between learners to find out whether telicity biases the use of Preterit in all proficiency levels.

Table 3. Total uses of Preterits with telics and atelics

\begin{tabular}{lrrc}
\hline & \multicolumn{1}{c}{ Atelic } & \multicolumn{1}{c}{ Telic } & Total of items \\
\hline Control group & $166(48 \%)$ & $183(52 \%)$ & 349 \\
A2 group & $142(50 \%)$ & $144(50 \%)$ & 286 \\
B1 group & $89(36 \%)$ & $155(64 \%)$ & 244 \\
B2 group & $127(49 \%)$ & $134(51 \%)$ & 261 \\
C1 group & $95(43 \%)$ & $127(57 \%)$ & 222 \\
\hline
\end{tabular}

There are significant differences between $A_{2}$ and $B_{1}, X^{2}(1, N=530)=9,29$, $p<.001$, and between $\mathrm{B}_{1}$ and $\mathrm{B}_{2}, X^{2}(1, N=505)=7,65, p<.001$, but not between $\mathrm{B} 2$ and $\mathrm{C}_{1}$. Data confirm that telicity effects are relevant in intermediate levels, and not at beginning stages of acquisition for English learners of L2 Spanish, as observed in Table 3. As predicted, the bias is clear only at B1. Since telicity interacts with specificity, animacy, and has an extra syntactic operation to value inherent cas, its effect gets into play later on in the acquisition process (Díaz et al., 2008; Guijarro-Fuentes, 2012).

\subsubsection{Punctuality effects with Preterits}

Table 4 shows the total uses of Preterits with durative and punctual predicates for all groups. Regarding punctuality, the chi-square shows that there are significant differences between the five groups, $X^{2}(4, N=1362)=10,65, p<.03$, also between the learners, $X^{2}(3, N=1013)=10,43, p<.02$. 
Table 4. Total uses of Preterits with durative and punctual predicates

\begin{tabular}{lrrc}
\hline & Durative & Punctual & Total of items \\
\hline Control group & $210(60 \%)$ & $139(40 \%)$ & 349 \\
A2 group & $193(67 \%)$ & $93(33 \%)$ & 286 \\
B1 group & $133(55 \%)$ & $111(45 \%)$ & 244 \\
B2 group & $167(64 \%)$ & $94(36 \%)$ & 261 \\
C1 group & $132(59 \%)$ & $90(41 \%)$ & 222 \\
\hline
\end{tabular}

However, when we look at results we find that they do not follow the prototypical association (punctual-Preterit), but durative-Preterit. The fact is that punctual predicates are a very small set of predicates in the present study (and also in general). For this reason, in Table 5 we have the total uses of punctual predicates with Preterits and Imperfects.

Table 5. Total uses of punctual predicates with Preterit and Imperfect

\begin{tabular}{lrcc}
\hline & Preterit & Imperfect & Total of items \\
\hline Control group & $139(85 \%)$ & $23(15 \%)$ & 162 \\
A2 group & $93(85 \%)$ & $16(15 \%)$ & 109 \\
B1 group & $111(92 \%)$ & $9(8 \%)$ & 120 \\
B2 group & $94(92 \%)$ & $8(8 \%)$ & 102 \\
C1 group & $90(97 \%)$ & $3(3 \%)$ & 93 \\
\hline
\end{tabular}

As expected, punctuality biases the use of the Preterit in all groups. The chisquare test for the five groups shows significant differences, $X^{2}(4, N=586)=12,80$, $p<.01$, and also among learners $X^{2}(3, N=424)=8,89, p<.03$. Surprisingly, only the chi-square tests which contrast $C_{1}$ and the control group, $X^{2}(1, N=255)=7,77$, $p<.001$, and the $\mathrm{A}_{2}$ and $\mathrm{C} 1, X^{2}(1, N=202)=7,73, p<.001$, show significant differences. We conclude that the effect of punctuality increases in $\mathrm{C}_{1}$, which makes sense if we take into account that $\mathrm{C} 1$ learners has been highly exposed to the bias of native speakers.

The results indicate that punctuality is associated with Preterit in all groups, and that the effect is reinforced in advanced levels. This confirms Bickerton's proposal, and in fact it might be also related to the default past tense marker first. Punctuality is a temporal marker related to the cognitive moment (Engelberg, 1999). The prototypical association punctual-Preterit is very strong for all groups. 


\subsubsection{Use of Imperfect}

Our third research question is about the aspectual features which bias the use of the Imperfect. Data were coded taking into account the same aspectual oppositions we tested for Preterit (dynamic/state, telic/atelic, punctual/durative).

\subsubsection{Stativity effects with Imperfect}

Table 6 presents the total uses of Imperfects with states and dynamic predicates. The chi-square test shows that there are not significant differences in the use of Imperfect with stative and dynamic predicates among the five groups, $X^{2}(4$, $N=492)=5,68,0,22$.

Table 6. Total uses of Imperfects with stative and dynamic predicates

\begin{tabular}{lccc}
\hline & Stative & Dynamic & Total of items \\
\hline Control group & $55(50 \%)$ & $56(50 \%)$ & 111 \\
A2 group & $46(54 \%)$ & $39(46 \%)$ & 85 \\
B1 group & $60(59 \%)$ & $42(41 \%)$ & 102 \\
B2 group & $93(63 \%)$ & $54(37 \%)$ & 147 \\
C1 group & $29(62 \%)$ & $18(38 \%)$ & 47 \\
\hline
\end{tabular}

However, as observed in Table 7, the chi-square test for the total uses of states with Preterit and Imperfect shows significant differences among the five groups, $X^{2}(4, N=501)=46,56, p<.001$.

Table 7. Total uses of states with Preterit and Imperfect

\begin{tabular}{lccc}
\hline & Preterit & Imperfect & Total of items \\
\hline Control group & $85(61 \%)$ & $55(39 \%)$ & 140 \\
A2 group & $45(50 \%)$ & $46(50 \%)$ & 91 \\
B1 group & $22(27 \%)$ & $60(73 \%)$ & 82 \\
B2 group & $32(25 \%)$ & $93(75 \%)$ & 125 \\
C1 group & $34(54 \%)$ & $29(64 \%)$ & 63 \\
\hline
\end{tabular}

Significant differences among the five groups regarding the total uses of states with Preterit and Imperfect allows paying attention to data. The chi-square test for the contrast between $\mathrm{A}_{2}$ and $\mathrm{B}_{1}$ shows significant differences, $X^{2}(1, N=173)=9,30$, $p<.001$, but not for $\mathrm{B}_{1}$ and $\mathrm{B}_{2}$. The test for $\mathrm{B}_{2}$ and $\mathrm{C}_{1}$ also shows significant differences $X^{2}(1, N=188)=14,80, p<.001$. The percentage of states with Imperfects increases from $50 \%$ in $\mathrm{A}_{2}$ to $73 \%$ and $75 \%$ in $\mathrm{B}_{1}$ and $\mathrm{B}_{2}$, respectively. Data indicate $\mathrm{B}_{1}$ and $\mathrm{B}_{2}$ learners associate states with Imperfect. Thus, there are differences in proficiency levels regarding stativity effects. Against our prediction, stativity, 
which is a lexical feature, and not a syntactic feature, influences the use of Imperfect in intermediate level.

\subsubsection{Durativity effects with Imperfect}

The chi-square test for the total uses of Imperfects with durative and punctual predicates shows significant differences among the five groups, $X^{2}(4$, $N=492)=20,11, p<.001$, and also among learners, $X^{2}(3, N=381)=12,05, p<.01$, and therefore attention will be given to durativity effects with Imperfect.

Table 8. Total uses of Imperfects with durative and punctual predicates

\begin{tabular}{lccc}
\hline & Durative & Punctual & Total of items \\
\hline Control group & $88(79 \%)$ & $23(21 \%)$ & 111 \\
A2 group & $69(81 \%)$ & $16(19 \%)$ & 85 \\
B1 group & $93(91 \%)$ & $9(9 \%)$ & 102 \\
B2 group & $139(95 \%)$ & $8(5 \%)$ & 147 \\
C1 group & $44(94 \%)$ & $3(6 \%)$ & 47 \\
\hline
\end{tabular}

Table 8 shows that most Imperfects are associated with durative predicates in all groups. The chi-square test for $\mathrm{A}_{2}$ and $\mathrm{B}_{1}$ shows significant differences, $X^{2}(1$, $N=187)=4,00, p<.04$. The percentage increases from $81 \%$ in $\mathrm{A}_{2}$ to $91 \%$ in $\mathrm{B} 1$, and it becomes even higher in $\mathrm{B}_{2}$ and $\mathrm{C}_{1}, 95 \%$ and $94 \%$ respectively, which indicates durativity effects at all levels.

However, and even though the chi-square test for the total uses of duratives with Preterit and Imperfect show significant differences for the five groups, $X^{2}(4$, $N=1268)=38,71, p<.001$, and also the four groups $X^{2}(3, N=970)=34,36, p<.001$, data in Table 9 do not indicate durativity effects.

Table 9. Total uses of duratives with Preterit and Imperfect

\begin{tabular}{lcrc}
\hline & Preterit & Imperfect & Total of items \\
\hline Control group & $210(70 \%)$ & $88(30 \%)$ & 298 \\
A2 group & $193(73 \%)$ & $69(27 \%)$ & 262 \\
B1 group & $133(59 \%)$ & $93(41 \%)$ & 226 \\
B2 group & $167(54 \%)$ & $139(56 \%)$ & 306 \\
C1 group & $132(75 \%)$ & $44(25 \%)$ & 176 \\
\hline
\end{tabular}

Against the expected association (durative-Imperfect), durative predicates are preferred with Preterit by native speakers, beginners and advanced learners, which seems to indicate that durativity does not bias the use of Imperfect. The intermediate groups behave differently. 
The fact is that there are durative predicates (opposed to punctual predicates) which are also telic, which implies that telicity is the reason for the bias. It would make sense that durativity affects the use of past tenses differently in level $\mathrm{B} 1$, as the chi-square for $\mathrm{A}_{2}$ and $\mathrm{B} 1$ shows, $X^{2}(1, N=488)=12,01, p<.001$, if together with telicity it distinguishes realizations, which are durative and telic predicates, from activities, which are only durative. We claim that durativity does not bias the use of Imperfect when it interacts with telicity, and therefore with specificity, animacy and inherent case.

Summarizing, durativity effects are somehow misleading because many durative predicates are also telic, and telicity effects seem stronger in level B1. When durativity interacts with telicity, telicity effects are predicted.

\subsubsection{Atelicity effects with Imperfect}

The chi-square test for the total uses of Imperfect with telic and atelic predicates shows significant differences among the five groups, $X^{2}(4, N=492)=19,87, p<.01$, and also among learners, $X^{2}(3, N=381)=15,18, p<.001$. All groups prefer atelics with Imperfect, as observed in Table 10.

Table 10. Total uses of Imperfect with telics and atelics

\begin{tabular}{lccc}
\hline & Atelic & Telic & Total of items \\
\hline Control group & $84(75 \%)$ & $27(25 \%)$ & 111 \\
A2 group & $62(73 \%)$ & $23(27 \%)$ & 85 \\
B1 group & $90(88 \%)$ & $12(12 \%)$ & 102 \\
B2 group & $133(90 \%)$ & $14(10 \%)$ & 147 \\
C1 group & $42(89 \%)$ & $5(11 \%)$ & 47 \\
\hline
\end{tabular}

Interestingly, there are significant differences between $\mathrm{A}_{2}$ and $\mathrm{B}_{1}, X^{2}(1$, $N=187)=7,13, p<.001$, but not between $\mathrm{B}_{1}$ and $\mathrm{B}_{2}$ or $\mathrm{C} 1$. Around $90 \%$ of Imperfects are used with atelics in $\mathrm{B}_{1}, \mathrm{~B}_{2}$ and $\mathrm{C}_{1}$. Atelicity effects with Imperfect increases at the intermediate level, where learners are processing both atelicity together with telicity effects. Nevertheless, and even though the chi-square test for the total uses of atelics with Imperfect and Preterit shows significant differences, $X^{2}(4, N=1030)=38,48, p<.001$, there is not preference of use of atelics with Imperfect, as observed in Table 11.

A closer look at the data in Table 11 reveals that A2 learners prefer atelics with Preterits, probably because at that moment of the language acquisition process $\mathrm{L}_{1}$ transfer is stronger that atelicity effects for English Li learners, and therefore they use Preterit in imperfective contexts. 
Table 11. Total uses of atelics with Preterit and Imperfect

\begin{tabular}{lrrc}
\hline & Preterit & Imperfect & Total of items \\
\hline Control group & $166(66 \%)$ & $84(34 \%)$ & 250 \\
A2 group & $142(70 \%)$ & $62(30 \%)$ & 204 \\
B1 group & $89(50 \%)$ & $90(50 \%)$ & 179 \\
B2 group & $127(49 \%)$ & $133(51 \%)$ & 260 \\
C1 group & $95(69 \%)$ & $42(31 \%)$ & 137 \\
\hline
\end{tabular}

\section{Discussion and conclusion}

The results of this study partially support the predictions of our Refined Lexical Hypothesis, i.e. lexical aspectual features bias grammatical aspect in initial stages and predicative aspectual features at a later stadium, together with L1 influence and the Feature Assembly Hypothesis. Dynamicity and punctuality effects are strong at all proficiency levels. Telicity effects become evident in intermediate levels, as expected because it interacts with animacy, specificity and inherent case. Unpredictably, stativity effects become evident in intermediate level.

As predicted, we found differences between lexical aspectual features as dynamicity and punctuality, and syntactic aspectual features as telicity. Dynamicity and punctuality bias the use of Preterit at all proficiency levels, while telicity, which interacts with animacy, specificity and inherent case, affects the use of the Preterit in intermediate levels. Students' use of Imperfect is influenced by durativity, but its effects are misleading because of interaction with telicity (and other syntactic features). Even though durativity is a lexical aspectual feature, when it interacts with telicity, telicity effects are stronger. For this reason, intermediate learners also prefer the Imperfect with states. Syntactic complexity makes learners pay attention to several lexical features in intermediate levels to use the Imperfect. They are still reassembling the imperfective features associated with the new morphological form. We argue that learners are still figuring out the meaning of Imperfect in this proficiency level, and when durativity interacts with telicity, they pay attention to stativity.

We also found atelicity effects when we focus on the total uses of Imperfects with telic and atelic predicates, but not when we focus on the total uses of atelics with Imperfects and Preterits. The fact that states and atelics do not behave as expected has to do with the diversity of both atelic and stative predicates. Many atelic predicates are stative or durative. Thus atelicity effects are derived from durativity and stativity effects, and as already seen, durativity effects are cancelled when it interacts with telicity, whereas stativity effects are only in B1. 
Anyhow, results reveal that some features bias the use of past tenses in all participants, not only learners, whereas other features bias only learners' production. Following Bickerton (1981), we claim that punctuality association with Preterit is a semantic universal, and for this reason the bias is for all groups. Dynamicity bias the use of Preterit in all learners. Telicity biases the use of Preterit in intermediate levels, whereas stativity biases the use of Imperfect also in intermediate levels. The results suggest that the challenge for learners in intermediate level is to figure out the meaning of the new morphological forms, i.e. the Imperfect and the preposition $a$ in VP, and also reject the imperfective meanings of the English Simple Past (Domínguez et al., 2017).

Even though we found that Preterit is preferred by all learners, and also native speakers, there are significant differences between $A_{2}$ and $B_{1}$ level which supports L1 transfer, i.e. Preterit is used in perfective and imperfective contexts, (Salaberry \& Shirai, 2001; Slabakova, 2001). English learners of L2 Spanish transfer the semantic meaning of their Simple Past to Preterit. Their use of Imperfect increases in intermediate levels, whereas the use of the Preterit decreases. Future research will measure the influence of foregrounding narrative in the preference of Preterit.

We conclude that the use of past verbal morphology by English learners of L2 Spanish in this study shows that different aspectual oppositions affect the use of both the Preterit and the Imperfect in different proficiency levels: the dynamic/ stative and the punctual/durative distinction bias the Preterit at all levels; telicity bias the Preterit in intermediate level. Although the punctual/durative opposition bias the Imperfect, its effect is cancelled in B1 when durativity interacts with telicity in predicates as escribir una carta 'write a letter'. For this reason the dynamic/ stative opposition influences the use of Imperfect in intermediate level.

\section{References}

Andersen, R. (1991). Developmental sequences: The emergence of aspect marking in second language acquisition. In T. Huebner, \& C.A. Ferguson (Eds.), Crosscurrents in Second Language Acquisition and Linguistic Theories (pp. 115-138). Amsterdam: John Benjamins. https://doi.org/10.1075/lald.2.17and

Andersen, R., \& Shirai, Y. (1996). Primacy of aspect in language acquisition. In W. Ritchie, \& T. Bathia (Eds.), Handbook of Second language Acquisition (pp. 527-570). San Diego: Academic Press.

Bardovi-Harlig, K. (1994). Anecdote or evidence? Evaluating support for hypotheses concerning the development of tense and aspect. In E. Tarone, S. M. Gass, \& A. D. Cohen (Eds.), Research Methodology in SLA (pp. 41-6o). Hillsdale, NJ: Lawrence Erlbaum.

Bickerton, D. (1981). Roots of Language. Ann Harbor, Mich.: Karoma Press. 
Comajoan, Ll. (2013). Tense and Aspect in Second Language Spanish. In K.L. Geeslin (Ed.), The Handbook of Spanish Second Language Acquisition (pp. 235-252). New York: John Wiley and Sons.

Diaubalick, T., \& Guijarro Fuentes, P. (2017). L1 effects as manifestations of individual differences in the L2 acquisition of the Spanish tense-aspect-system. In K. Bellamy, M.W. Child, P. González, A. Muntendam, \& M.C. Parafita Couto (Eds.), Multidisciplinary Approaches to Bilingualism in the Hispanic and Lusophone World. Issues in Hispanic and Lusophone Linguistics 13 (pp. 9-40). Amsterdam/Philadelphia: John Benjamins. https://doi.org/10.1075/ihll.13.02dia

Díaz, L., Bel, A., \& Bekiou, K. (2008). Interpretable and uninterpretable features in the acquisition of Spanish past tenses. In J. Muñoz Liceras, H. Zobl, \& H. Goodluck (Eds), The role of formal features in Second Language Acquisition (pp. 484-512). NJ: Lawrence Erlbaum.

Domínguez, L., Arche, M., \& Myles, F. (2017). Spanish Imperfect revisited: Exploring L1 influence in the reassembly of imperfective features onto new L2 forms. Second Language Research, 33(4), 431-457. https://doi.org/10.1177/0267658317701991

Domínguez, L., Tracy-Ventura, N., Arche, M., Mitchell, R., \& Miles, F. (2013). The role of dynamic contrasts in the L2 acquisition of Spanish past tense morphology. Bilingualism: Language and Cognition, 16(3), 558-577. https://doi.org/10.1017/S1366728912000363

Engelberg, S. (1999). The magic of the moment: what it means to be a punctual verb. Proceedings of the 25th Meeting of the Berkeley Linguistic Society, 109-121. https://doi.org/10.3765/bls.v25i1.3046

Gavruseva, E. (2002). Is there primacy of aspect in child L2 English? Bilingualism Language and Cognition, 5(2), 109-30. https://doi.org/10.1017/S1366728902000226

González, P., \& Quintana Hernández, L. (2018). Inherent aspect and L1 transfer in the L2 acquisition of Spanish grammatical aspect. Modern Language Journal, 102(3), 611-625.

González, P. (2003). Aspects on aspect. Theory and applications of grammatical aspect in Spanish. Utrecht: Utrecht Institute of Linguistics.

González, P. (2013). Research design: A two-way predicational system is better than a four-way approach. In R. M. Salaberry, \& Ll. Comajoan (Eds), Research Design and Methodology in Studies on L2 Tense and Aspect (pp. 159-186). Amsterdam: Mouton de Gruyter. https://doi.org/10.1515/9781934078167.159

Guijarro-Fuentes, P. (2012). The acquisition of interpretable features In L2 Spanish: Personal a. Bilingualism: Language and Cognition, 15(4), 701-720. https://doi.org/10.1017/S1366728912000144

Lardiere, D. (2009). Some thoughts on the contrastive analysis of features in second language acquisition. Second Language Research, 25(2), 173-227. https://doi.org/10.1177/0267658308100283

Moens, M., \& Steedman, M. (1988). Temporal ontology and temporal reference. Journal of Computational Linguistics, 14(2), 15-28.

Montrul, S., \& Slabakova, R. (2002). The L2 acquisition of morphosyntactic and semantic properties of the aspectual tenses preterite and imperfect. In A.T. Pérez Lerroux, \& J. Muñoz Liceras (Eds.), The acquisition of Spanish morphosyntax (pp. 115-151). Amsterdam: Springer Netherlands. https://doi.org/10.1007/978-94-010-0291-2_5

Montrul, Silvina. (2004). The Acquisition of Spanish: Morphosyntactic Development in Monolingual and Bilingual L1 acquisition and Adult L2 Acquisition. Amsterdam: John Benjamins. 
Salaberry, R. (2000). The development of past tense morphology in L2 Spanish. Studies in Bilingualism. Amsterdam/Philadelphia: John Benjamins.

Salaberry, R., \& Shirai, Y. (2002). L2 Acquisition of tense-aspect morphology. Language acquisition and language disorders. Amsterdam/Philadelphia: John Benjamins. https://doi.org/10.1075/lald.27

Slabakova, R. (2001). Telicity in the second language. Language Acquisition and Language Disorders. Amsterdam: John Benjamins. https://doi.org/10.1075/lald.26

Smith, C. (1991). The parameter of aspect. Studies in Linguistics and Philosophy. Dordrecht: Kluwer Academic Publishers. https://doi.org/10.1007/978-94-015-7911-7

Vendler, Z. (1957). Verbs and times. Philosophical review, 66, 143-160. https://doi.org/10.2307/2182371

Verkuyl, H. (1993). A theory of aspectuality. The interaction between temporal and atemporal structure. Cambridge studies in linguistics 64. Cambridge: CUP. https://doi.org/10.1017/CBO9780511597848

Vincendeau, S. (1995). Paroles en l'air. Francia.

\section{Address for correspondence}

Lucía Quintana Hernández, Ph.D.

Assistant Professor

Universidad de Huelva

Departamento de Filología

Facultad de Humanidades. Pabellón 11

Campus El Carmen, Avenida de las Fuerzas Armadas S/N.

21007 Huelva

Spain

lucia.quintana@dfesp.uhu.es

https://orcid.org/oooo-ooo3-4738-9693

\section{Publication history}

Date received: 7 January 2019

Date accepted: 2 December 2019 